\title{
The Role of Human Resource Information System in the Process of Manpower Activities
}

\author{
Ama F. Karikari', Peter Agyekum Boateng1, Evans 0. N. D. Ocansey ${ }^{2}$ \\ ${ }^{1}$ Department of Management Studies, Valley View University, Greater Accra, Ghana \\ ${ }^{2}$ Department of Accounting, Valley View University, Greater Accra, Ghana \\ Email: amakarikari@vvu.edu.gh
}

Received 5 May 2015; accepted 26 June 2015; published 29 June 2015

Copyright (C) 2015 by authors and Scientific Research Publishing Inc.

This work is licensed under the Creative Commons Attribution International License (CC BY). http://creativecommons.org/licenses/by/4.0/

c) (i) Open Access

\section{Abstract}

The evolution of technology has encouraged organizations to use human resource information systems (HRIS). HRIS is perceived to contribute to the effectiveness of manpower activities (human resources planning) in organizations. This paper interviewed two HRIS managers in the hospitality industry in Greater Region (Ghana) to identify the benefits, contributions and the challenges of HRIS. It was revealed that HRIS identified unfilled positions, accurately analyzed each job position and its job title in the organization, providing insight into organizational training needs, selected the right persons to be trained at the right time, evaluated the effectiveness of training programs and made faster and better decisions about successor ranking. It was therefore concluded that HRIS played a major role in the management of human resources. Organizations should integrate HRIS with other organizational systems to facilitate speedily sharing of information and decision making.

\section{Keywords}

Information System, Human Resource Information System, Human Resource Management

\section{Introduction}

With the increasing effect of globalization and technology, organizations have started to use information systems in various functions and departments in the last decades. Human Resources Management is one of the departments that mostly use management information systems [1]. Human Resources Units in organizations now place much emphasis on sharing information, especially ones that affect the workforce [2] [3]. As a result, some 
organizations deem it fit to employ HRIS in their transactions [4].

Human Resource Information System (HRIS) is a computer-based system that is used to manage the administration of HR processes and procedures. Its purpose is to become more efficient in providing better information for decision making [5] [6]. Mayfield, Mayfield and Lunce [7] added that the "functions of HRIS comply with organizational interests in maintaining and managing the human capital based on the organizational vision and the strategy of achieving that vision". This contributes to effective decision making which may guide spending of human resources in an organization.

According to Kumar [8], to meet the competition in the global market, firms need to balance their available resources (human and capital) to achieve the desired profitability and survival. It is believed that management of human resources is the most important function for every organization that wants to have a competitive edge over its competitors because systems in organizations are formed and ran by humans. This paper therefore researched into the benefits of HRIS, its contributions to organizations and the challenges associated with its usage.

The research reviewed various articles to understand the concept of HRIS, and interviewed HRIS managers to identify the benefits and contributions of HRIS, the challenges of using this system, profiled findings, conclusion and recommendations of the study.

\section{Literature Review}

It is perceived that technology is everything to human existence. It is assumed by Mathis and Jackson [9] that technology enhances human resource (HR) activities at the workplace (2010). In support of that Lederer [4] declared that HRIS has been in operation since 1960s (1984). Researchers averred that whenever HRIS function was computerized, fast decision making was able to take place in the development, planning, and administration of HR because data became much easier to store, retrieve, update, classify, and analyze. Therefore, HRIS can strengthen an organization's character in general [10]. Tracking information concerning an applicant's or an employee's qualifications and demographics, recruitment, professional development, performance evaluation, payroll, retention, and attrition are essential for success at the HR functional level (Harris and Desimone, 1995); so the introduction of HRIS.

HRIS applications show contrast in its functionality from administrative applications, talent management applications, workforce management applications, service delivery applications and workforce analysis and decision support applications [11] [12]. This means a shift has been made from labour-intensive HRM to technology-intensive HRM.

\subsection{Objectives of Human Resource Information Systems}

HRIS function was computerized for fast decision-making to take place in the development, planning, and administration of HR because it makes data easier to store, retrieve, update, classify, and analyze in an organization [10]. Rao [13], therefore, submits that HRIS is designed to achieve the following objectives:

- To offer an adequate, comprehensive and ongoing information system about the people and the job;

- To supply up to date information at reasonable cost;

- To offer data security and personal privacy.

\subsection{Types of Human Resource Information System}

Information systems increase administrative efficiency and produce reports capable of improving decision making [14]. Based on this premise, Kumar (2012) [10] identified three dimensions of HRIS:

- Operational Human Resource Information System - Kumar (2012) [10] stated that an operational human resource information system provides the manager with data to support routine and repetitive human resource decisions; a number of operational level information systems collect the data relating to human resources including the information about the organization's positions, workforce and governmental regulations.

- Tactical Human Resource Information System - are used to provide managers with support for decisions related with allocation of resources [15]. Major important decisions in human resource management include recruitment decisions; job analysis and design decisions, training and development decisions, and employee 
compensation plan decisions [15].

- Strategic Human Resource Information System-helps the organization to implement strategic human resource management [10].

\subsection{Needs of Human Resource Information System in Organizations}

There are several rationales for using HRIS in organizations. Thite and Kavanagh [16] seem to suggest that:

- HRIS gives holistic knowledge about operations which can be shared among departments/units within the companies;

- It provides opportunity for companies to gather data to improve on time and quality of decision making;

- It provides variety of reports to boost good organization of administrative functions.

Hendrickson [17] averred that execution of HRIS changes traditional HR procedures. It is expected that HRIS will provide practical steps for realization of departmental goals. He, therefore, postulated some justifications base on the following elements: Cost decrease, Saving Time, Competency Management, and Knowledge Management.

\subsection{Overview of Manpower Planning Process}

Forecasting of staff requirements is well established in Human Resource Management vocabulary. It is assumed that manpower planning (human resource planning) has influence on companies' performance because whatever businesses do, they cannot ignore the human aspect. Therefore, Armstrong [18] seems to suggest that manpower planning contributes to organizations earnings/returns by reducing costs, employees training, associating with modern environmental and technological changes are several considerable advantages of human resource planning.

By observation, a considerable number of management challenges may be resolved through the recruitment of capable employees.

In addition, Tansley, Newell and William [19] identified four manpower planning activities, namely,

- Staffing: This HR activity cannot be overlooked in any established enterprise. They indicated that staffing enables companies to know current employees strength in order to predict for the future.

- Training and Development: Usually done to beef up employees capabilities to meet current business trends. This HR activity is enforced often after conducting performance appraisal. By this means, training and development might assist management to identify labour deficiencies, if any, in the company.

- Career Development: Career development appears to be a crucial HR exercise which project into the future. This practice seems to endorse succession planning principles to guarantee the enterprises continual existence. Career development gives employees the chance to upgrade themselves for mutual benefit. This HR activity creates the platform to either add to the number of employees or lessen the size.

- Downsizings: Management decision with respect to upcoming downsizing should be reported to officers to prevent any operations interruption.

\subsection{The Role of Human Resource Information System in the Process of Manpower Activities}

Barron, Chhabra, Hanscome and Henson [20] perceived HRIS to emphasize mainly the "retention of capable employees and the reduction costs associated with maintaining them". HRIS also gives opportunity to HR professionals to enhance their contribution to the long-term plan of enterprises [21].

Firstly, by automating and devolving many routine HR tasks to line management, HRIS provide HR professionals with the time needed to direct their attention towards more business critical and strategic level tasks, such as leadership development and talent management [21].

Secondly, HRIS provides an opportunity for HR to play a more strategic role, through their ability to generate metrics which can be used to support strategic decision making [17] [22] [23].

Thirdly, HRIS support long range planning with information for labour force planning and supply and demand forecast; staffing with information on equal employment, separations and applicant qualifications; and development with information on training programs, salary forecasts, pay budgets and labour or employee rela- 
tions with information on contract negotiations and employee assistance needs [24] [25].

Fourthly, Risk and security management is another crucial function which can be derived by HRIS by following private and highly sensitive individual data and multiplatform security aspects which are perhaps the most serious factors that need to be taken into consideration [26].

Dessler [27] added that, HRIS influence manpower activities by:

- Making a regular analysis of the human resource needs of the company through matching the supply of human resource with the demand for it, the system identifies unfilled positions accurately;

- Provides insights into organizational training needs by identifying deficiencies in employee's performance and then select the right persons to be trained at the right time after which the system evaluates the effectiveness of the training programs.

Wiblen, Grant and Dery [28] also asserted that, the performance related data and productivity information data embedded in the HRIS is used as evidence in employee grievance matters; careful documentation of employee performance, method of measuring the performance of employees and reporting system, which is critical to organizations.

\section{Methodology}

Cross-sectional descriptive research was used base on the distinctiveness of the observed facts. The population, however, included hotels in Greater Accra Region (Ghana) that use HRIS in their operations. Purposive sampling technique was employed to sample two (2) HRIS managers who were interviewed afterwards. Provision was made to record the conversation yet the in-charge was not comfortable with such medium. The researchers noted the responses given by the managers and afterwards were transcribed. Consensus was reached concerning the period for interactions among the Researchers and the Informants for mutual benefits. The Instrument for the study was structured interview and the specific core themes derived from the interview were developed for the content analysis including Cross-tabulation and Chi-square statistical tool.

\section{Findings and Discussion}

Hotel A: The HR Manager holds a Bachelor's Degree in Human Resource Management and has worked more than four (4) years. According to informant A, the hotel has above 100 employees; uses the HRIS "Persol" which has been implemented over five (5) years and is interact with only the Human Resource Professionals in the company.

Hotel B: The informant has a Bachelor's degree in Human Resource Management; a Master's degree in Accounting and Finance, and has worked as the Human Resource officer for more than four years. The information in Table 1 indicates that the interviewees familiar with HRIS since they have being using the system for more than four years.

Table 1. Summary of informants and company profile.

\begin{tabular}{ccc}
\hline Position & Hotel A & Hotel B \\
\hline Education & HR officer & HR officer \\
Tenure & Bachelor's degree & MBA, accounting \& finance \\
Number of employees & Over 4 years & Over 4 years \\
Length of implementation of HRIS & Over 100 100 \\
Type of HRIS & Over 5 years & Over 5 years \\
Is HRIS integrated with other systems & Persol & Personal manager \\
Who interacts with the HRIS & No & Yes \\
\hline
\end{tabular}

Source: Researchers field work (2015). 
A careful synthesis of the responses from A and B revealed that though using different systems, generally, there are many benefits (value) manpower activities derive from the HRIS, and this can be seen with regards to the responses give in Table 2. That is, the use of HRIS helps to identify unfilled positions accurately and analyze each job position with its title in an organization. It also provides insight into organizational training needs, select the right persons to be trained and evaluates the effectiveness of training programs. These findings are in agreement with Dessler [27]. He indicated that, HRIS influence manpower activities by:

- Making a regular analysis of the human resource needs of the company through matching the supply of human resource with the demand for it, the system identifies unfilled positions accurately;

- Provides insights into organizational training needs by identifying deficiencies in employee's performance and then select the right persons to be trained at the right time after which the system evaluates the effectiveness of the training programs.

Also, both A and B agreed that the system enhance faster and better decisions about successor ranking by identifying specific key positions and targeting specific employees as potential successors. However, the use of the system does not reduce recruitment cost.

With regards to HRIS contribution to effective succession planning, three main factors were identified in Table 3. These include identifying specific key positions and target specific employees as potential successors, making better and faster decisions about talent pipeline and successor ranking, and identifying and tracking high potential employees and implement development plans. This findings affirm what Dessler [25], Shiri [24] and Shibly [29] said that HR planning with HRIS makes it easier to follow workforce gaps, supports long range planning with information for labour force planning and supply and demand forecast; staffing with information on equal employment, separations and applicant qualifications; and development with information on training programs, salary forecasts, pay budgets and labour/employee relations with information on contract negotiations and employee assistance needs with the help of HR knowledge systems

On the issue of performance management with HRIS, three main factors were also identified in this section; analyzing employees' skills and qualification, monitoring the progress of aligning employees' goals with corporate goals, and supporting performance-oriented compensation process. It confirmed the study conducted by Wiblen, Grant and Dery [28] who asserted in their findings that the performance related data and productivity information data embedded in the HRIS is used as evidence in employee grievance matters; careful documentation of employee performance, method of measuring the performance of employees and reporting system, which is critical to organizations. The chi-square test further revealed that, at $99 \%$ confidence level, these contributions of HRIS to the organizations are very significant.

Considering Table 4, four (4) main challenges were identified as the main challenges associated with Manpower activities in the organizations which included; forecasting demand and supply of labour, access to information, cost of recruitment and workforce shortage. The Chi-square test further revealed that these challenges are very significant at $1 \%$ significant level. This implies that, at $99 \%$ confidence level, we can conclude that these factors associated with Manpower activities significantly affected both organizations prior and after the introduction of the HRIS.

Table 2. Benefits of human resource information systems.

\begin{tabular}{|c|c|c|}
\hline Benefits & Hotel A & Hotel B \\
\hline 1. Does HRIS identify unfilled positions accurately? & Yes & Yes \\
\hline 2. Does HRIS analyze each job position and its job title in an organization? & Yes & Yes \\
\hline 3. Does HRIS reduce recruiting cost? & No & No \\
\hline 4. Does HRIS provide insights into organization training needs? & Yes & Yes \\
\hline 5. Does HRIS select the right persons to be trained at the right time? & Yes & Yes \\
\hline 6. Does HRIS evaluate the effectiveness of training programs? & Yes & Yes \\
\hline $\begin{array}{l}\text { 7. Does HRIS make better and faster decisions about successor ranking } \\
\text { by identifying specific key positions and targeting specific employees as potential successors? }\end{array}$ & Yes & Yes \\
\hline
\end{tabular}

Source: Researchers field work (2015). 
Table 3. Contributions of HRIS to organizations.

\begin{tabular}{|c|c|c|c|}
\hline \multicolumn{2}{|c|}{ Effective Succession Planning } & \multicolumn{2}{|c|}{ Performance Management } \\
\hline \multicolumn{2}{|c|}{$\begin{array}{l}\text { Identify specific key positions and target specific e } \\
\text { mployees as potential successors }\end{array}$} & \multicolumn{2}{|c|}{ Analyze employees skills and qualification } \\
\hline \multicolumn{2}{|c|}{$\begin{array}{l}\text { Make better and faster decisions about } \\
\text { talent pipeline and successor ranking }\end{array}$} & \multicolumn{2}{|c|}{$\begin{array}{l}\text { Monitor the progress of aligning } \\
\text { employees goals with corporate goals }\end{array}$} \\
\hline \multicolumn{2}{|c|}{$\begin{array}{l}\text { Identify and track high potential employees } \\
\text { and implement development plans }\end{array}$} & \multicolumn{2}{|c|}{ Support performance-oriented compensation proces } \\
\hline \multicolumn{4}{|c|}{ Test Statistic } \\
\hline Chi-Square & 0.0124 & Chi-Square & 0.00254 \\
\hline $\mathrm{df}$ & 2 & df & 2 \\
\hline \multicolumn{2}{|c|}{ Asymp. } & \multicolumn{2}{|c|}{ Asymp. } \\
\hline Sig. & 0.000 & Sig. & 0.000 \\
\hline
\end{tabular}

*significant if p-value (Sig.) < 0.01. Source: Researchers field work (2015).

Table 4. Challenges associated with manpower activities.

\section{Challenges}

Forecasting demand and supply of labor

Access to information

Cost of recruitment

Workforce Shortage

Test Statistics

Chi-Square

df

Asymp. Sig.
0.0104

3

0.000

*significant if p-value (Sig.) < 0.01. Source: Researchers field work (2015).

\section{Conclusion}

HRIS is an integrated system used to gather, store and analyze information regarding an organization's human resources' comprising databases, computer applications, and hardware and software necessary to collect, record, store, manage, deliver, present and manipulate data for human resources function [29]. The study concludes that HRIS is an excellent tool for Human Resource Planning (HRP). It enhances the identification of unfilled positions accurately and analyzes each job position with its title in an organization. It also provides insight into organizational training needs, selects the right persons to be trained and evaluates the effectiveness of training programs, but has the challenges of forecasting demand and supply of labour, access to information, cost of recruitment and workforce shortage.

\section{Recommendations}

Considering the findings, the study recommended that in using human resource information system, organizations should integrate the HRIS system with other organizational systems to speed information sharing and decision making.

The disguised hotels may also contact educational institutions like training colleges, polytechnics and universities in order to cope with the challenge of workforce shortages timely. By doing this, organizations will have information concerning labour and thereby reduce labour shortage challenges.

Further, they should implement the recommendation from their HRIS concerning succession planning and training of employees in order to accomplish the desired performance of the organization. 


\section{References}

[1] Bal, Y., Bozkurt, S. and Ertemsir, E. (2012) The Importance of Using Human Resources Information Systems (HRIS) and a Research on Determining the Success of HRIS. Knowledge and Learning: Global Empowerment. Proceedings of the Management, Knowledge and Learning International Conference 2012, International School for Social and Business Studies, Celje, 20-22 June 2012, 53-62.

[2] Rodriguez, J.M. and Ventura, J. (2003) Human Resource Management Systems \& Organizational Performance: An Analysis of the Spanish Manufacturing Industry. International Journal of Human Resource Management, 14, 12061226.

[3] Troshani, I., Jerram, C. and Rao, S. (2011) Exploring the Public Sector Adoption of HRIS. Industrial Management and Data Systems, 111, 470-488. http://dx.doi.org/10.1108/02635571111118314

[4] Lederer, A.L. (1984) Planning and Developing a Human Resource Information System. The Personnel Administrator, 29, 27-39.

[5] Armstrong, M. (2009) Strategic HRM-The Key to Improved Business Performance. Chartered Institute of Personnel and Development. British Library Cataloguing in Publication Data. Printed in Great Britain by the Cromwell Press, Trowbridgee.

[6] Tannenbaum, S.I. (1990) Human Resource Information Systems: User Group Implications. Journal of Systems Management, 41, 27-32.

[7] Mayfield, M., Mayfield, J. and Lunce, S. (2003) Human Resource Information Systems: A Review \& Model Development. American Society for Competitiveness, 11, 139-151.

[8] Kumar, R. (2012) Human Resource Information System: An Innovative Strategy for Human Resource Management. Gian Jyoti E-Journal, 1, 1-12.

[9] Mathis, R.L. and Jackson, J.H. (2010) Human Resource Management. 13th Edition, South-Western College Publishing, Ohio.

[10] Sadri, J. and Chatterjee, V. (2003) Building Organizational Character through HRIS. International Journal of Human Resources Development and Management, 3, 84-98. http://dx.doi.org/10.1504/IJHRDM.2003.001048

[11] Florkowski, G.W. and Olivas-Luján, M.R. (2006) The Diffusion of Human Resource Information-Technology Innovations in US and Non US Firms. Personnel Review, 35, 684-710. http://dx.doi.org/10.1108/00483480610702737

[12] Beulen, E. (2009) The Contribution of a Global Service Provider's Human Resources Information Systems (HRIS) to Staff Retention in Emerging Markets Comparing Issues \& Implications in Six Developing Countries. Information Technology and People, 22, 270-288. http://dx.doi.org/10.1108/09593840910981446

[13] Rao, V.P.S. (2000) Human Resource Management: Text and Cases. Excel Books, New Delhi, 548-550.

[14] DeSanctis, G. (1986) Human Resource Information Systems: A Current Assessment. MIS Quarterly, 10, 15-27. http://dx.doi.org/10.2307/248875

[15] Troshani, I., Jerram, C. and Hill, S.R. (2011) Exploring the Public Sector Adoption of HRIS. Industrial Management \& Data Systems, 111, 470-488. http://dx.doi.org/10.1108/02635571111118314

[16] Hendrickson, A.R. (2003) Human Resource Information Systems: Backbone Technology of Contemporary Human Resources. Journal of Labor Research, 24, 381-394. http://dx.doi.org/10.1007/s12122-003-1002-5

[17] Armstrong, M. (2006) A Handbook of Human Resource Management Practice. 10th Edition, Kogan Page Limited, Cambridge University Press, Cambridge.

[18] Tansley, C., Newell, S. and William, H. (2001) Effecting HRM-Style Practices through an Integrated Human Resource Information System: An E-Greenfield Site? Personnel Review, 30, 351-371.

[19] Thite, M. and Kavanagh, M.J. (2011) Evolution of Human Resource Management and Human Resource Information Systems: The Role of Information Technology. http://www.sagepub.com/upm-data/25450 Ch1.pdf

[20] Barron, M., Chhabra, D., Hanscome, R. and Henson, R. (2004) Exclusive Panel Discussion: Tips and Trends in HRIS. HR Focus, 81, 6-7.

[21] Lawler, E.E. and Mohrman, S.A. (2003) HR as a Strategic Partner: What Does It Take to Make It Happen? Human Resource Planning, 26, 15-29.

[22] Lawler, E.E., Levenson, A. and Boudreau, J.W. (2004) HR Metrics and Analytics: Use and Impact. Human Resource Planning, 27, 27-35.

[23] Lengnick-Hall, M.L. and Moritz, S. (2003) The Impact of E-HR on the Human Resource Management Function. Journal of Labor Research, 24, 365-379. http://dx.doi.org/10.1007/s12122-003-1001-6

[24] Shiri, S. (2012) Effectiveness of Human Resource Information System on HR Functions of the Organization-A Cross 
Sectional Study. US-China Education Review, A9, 830-839.

[25] Dessler, G. (2005) Human Resource Management. 10th Edition, Prentice Hall, Upper Saddle River.

[26] Karakanian, M. (2000) Are Human Resources Departments Ready for E-HR? Information Systems Management, 17, 31-35. http://dx.doi.org/10.1201/1078/43193.17.4.20000901/31250.6

[27] Dessler, G. (2008) Human Resource Management. Pearson Prentice Hall, Upper Saddle River.

[28] Wiblen, S., Grant, D. and Dery, K. (2010) Transitioning to a New HRIS: The Reshaping of Human Resources and Information Technology Talent. Journal of Electronic Commerce Research, 11, 251-267.

[29] Shibly, H. (2011) Human Resources Information Systems Success Assessment: An Integrative Model. Australian Journal of Basic and Applied Sciences, 5, 157-169. 